Jurnal Ilmial

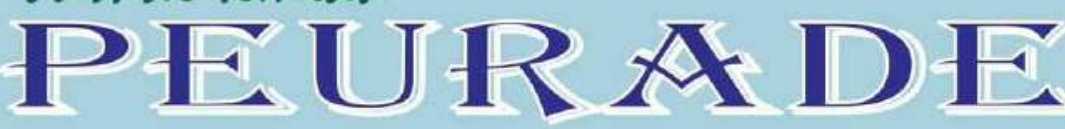

Vol. 5, No. 1, January 2017

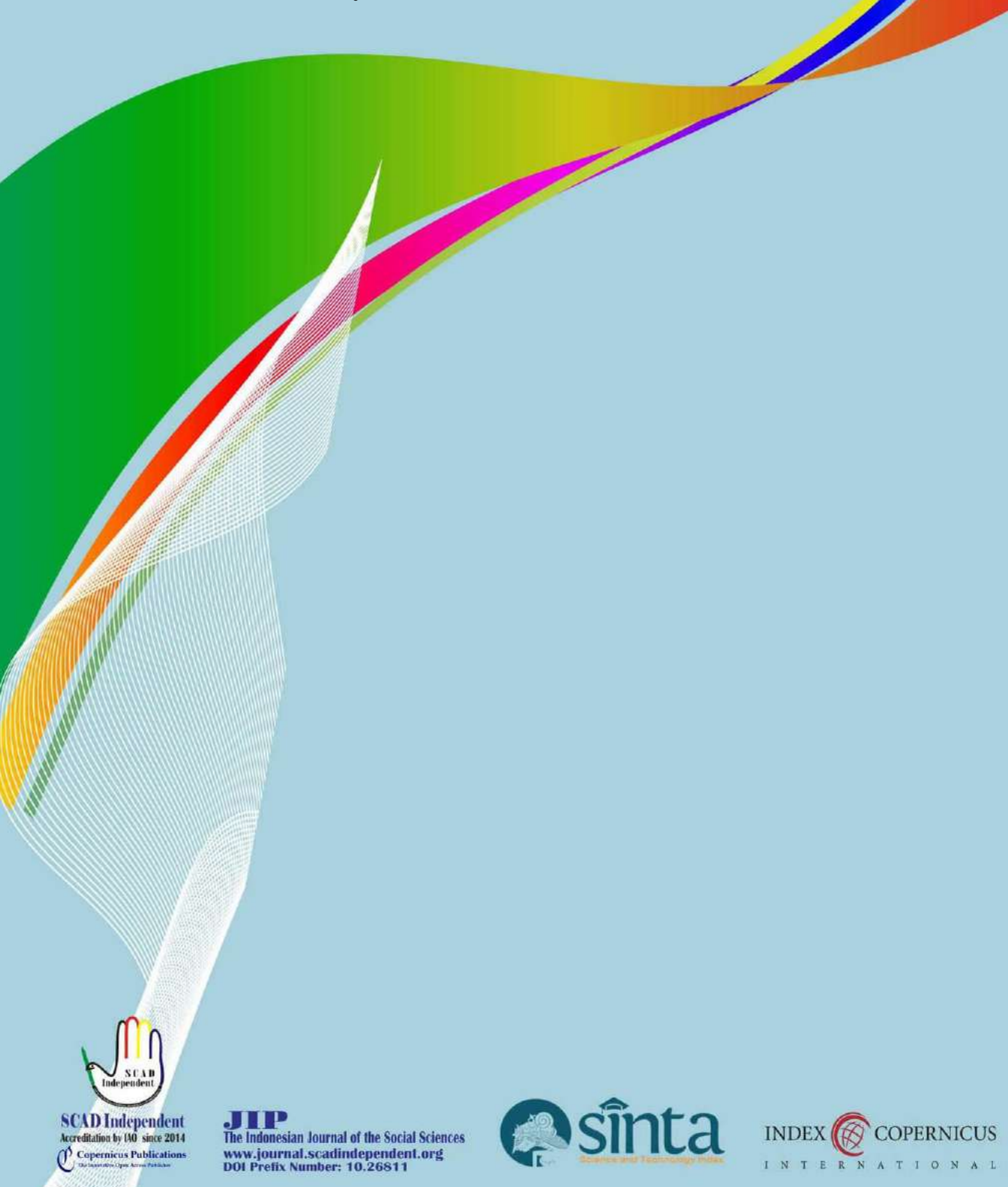




\title{
CHARACTERISTICS OF INDIVIDUALS AND WORKPLACE CONDITIONS WITH JOB SATISFACTION LECTURER HEALTH POLYTECHNIC OF ACEH
}

\author{
Teuku Salfiyadi \\ Lecturer of Health Polytechnic of Aceh, Indonesia \\ Contibutor Email: atjeh1983@live.com
}

Received: August 15, 2016

Accepted: August 26, 2016

Published: Jan 28, 2017

Article Url: http://journal.scadindependent.org/index.php/jipeuradeun/article/view/117

\begin{abstract}
As an organization that produces health services, one of the factors that determine the quality of product is personnel who worked with dedication and professionalism. This is achieved when the manager is able to give a satisfaction to all employees on the job. This study aimed to investigate the relationship individual and workplace characteristics with job satisfaction of employee. The populations of study were 32 employees of Environmental Health Department of Health Polytechnic of Aceh. Individual and workplace characteristic and job satisfaction were collecting by structural questionnaires. The product moment correlation was conducted to analysis of the data. The study showed individual and workplace characteristics were strongly correlation on job satisfaction $(p=0.000$ and $r=0.805)$ or $80.5 \%$ the independent variables are able to explain the dependent variable of job satisfaction is $r$-square $=0.647$, or by $64.7 \%$.
\end{abstract}

Keywords: Individual Characteristic, Workplace Condition, and Job Satisfaction 


\section{A. Introduction}

Based on Law No. 36 Year 2009 on Health states that the health system is organized based on the principle of humanity, balance, benefits, protection, respect for the rights and obligations, fairness and non-discriminatory. Health development aims to increase awareness, willingness and ability of healthy life for everyone to realize the degree of public health as high, as an investment for the development of productive human resources socially and economically, health is good health, both physically, mentally, spiritually and socially to enable everyone to live socially and economically productive (Ministry of Health RI, 2009: 32).

Health polytechnic of Aceh as an integral part of the overall system of National Education is education of healthcare professionals in two or more of the branches of science and technology in the health field. As an organization that produces health services, one of the factors that determine the quality of the product is personnel who worked with dedication and professionalism. This is achieved when the manager is able to cause satisfaction to all employees for their work, therefore the leadership of the Ministry Health polytechnic of Aceh should consider the factors that influence employee satisfaction. Qualities of service without the support of employee professionalism then these services are less able to run well (Profile of Poltekkes Kemenkes Aceh, 2005).

Health polytechnic of Aceh is a combination of several types of Diploma coaching Health under the Ministry of Health in the Aceh Province and established by decree of Minister of Health No. 1207/Menkes /SK/XI/2001 dated November 12, 2001 consisted of Nursing Department, Midwifery Department, Nutrition Department, Environmental Health Department, Dental Health Department, Nursing Department of Meulaboh and Langsa.

In performing its duties, Environmental Health Polytechnic of Aceh has vision and mission. Vision: "Making Health Polytechnic Aceh Being Health Manpower Education Institutions in Western Indonesia". Mission: "1) Improve the quality of human resources through the implementation of health personnel professional education and responsibility; 2) Perform community service activities primarily through scholarship and research in order to improve the welfare of the community" (Profile of Poltekkes Kemenkes Aceh, 2005). 
In seeking a quality service, Environmental Health Department of Health Polytechnic, MoH Aceh should consider some characteristics of individual employee satisfaction that include; age, tenure, and gender, and educational level. In addition, it is important to give the attention to the characteristics of workplace conditions that include; compensation, promotion, colleagues, supervision and work.

\section{B. Method}

The methodology in is research is quantitative descriptive analytic approach to determine the relationship lecturer Health Polytechnic of Aceh.

\section{Research Finding}

The observation of researchers lately either based on interviews researchers with various parties and based on the observations of researchers, it was found inequalities as follows; several employees of Environmental Health Department of Health Polytechnic of Aceh in performing work less disciplined, it is visible from working not as the rule, attitudes that often truant, late to work, some employees come at $09.00 \mathrm{am}$ and go back at 14:30 pm, and some employees are lazy and late to work but they did not get a warning from their superiors. Some employees do not obey and respect the instructions of superiors, for example when they go out of the office during working hours without any notice to the colleague/ boss.

In the provision of reward and punishment, diligent employees complained because in the implementation of the policies is not fair and reasonable. This is because there is no difference of reward and punishment for employees who diligent and lazy. They even have the same opportunity between lazy employees and diligent employees. Their rights as PNS are equal/no difference appreciation for instance monthly salary, every two years once they earn a regular salary increases, and every two/four years, got a promotion. Incentives received both special allowance and other incentives as well as other employees who are diligent or lazy get it same, Robert L, (1996).

Robbins (1996: 12) mention that the "system of wages and promotion policy that employees perceived fair, no doubt, and in 
accordance with their expectations affect employee satisfaction. To improve the quality of service of the employee's productivity, it is necessary to pay attention to employee satisfaction". When job satisfaction has been met, it will cause employees to work with the best of their ability, and with high productivity. Employees will be involved with the work, use of time and energy in his work, and putting the work as a central whole life, indicating the involvement of employees.

The system is a way which would run correctly in the organization, there is no doubt or no problem appears in an organization because their satisfaction already achieved what they want, Ariyanto, (2008).

Furthermore, Robbins (1996: 74) also argues that "employees who do not feel satisfied in performing job which is given by superiors, they will avoid the work, and will likely resign". Therefore, it is logic that an organization tries to find the sources that make job dissatisfaction. There is the possibility of employee absenteeism and less discipline in working are an employee's feeling of anti-climax, because they feel unsatisfied with the policy of the leader.

\section{Discussion}

1. General Description of Research Location

Health polytechnic of Aceh was established on November 12, 2001 with the Decree of the Minister of Health and Social Welfare of Republic of Indonesia No: 1207/Menkes/SK/XI/2001 which is seven (7) departments in the province. One of them is Environmental Health Department Health Polytechnic of Aceh

\section{Research Result}

a. Analysis result of Univarian Variable Independent

1) The description of the distribution of the individual characteristics of respondents

Individual characteristic of Environmental Health Department Employee of Poltekkes MoH Aceh consist of age, length of work, gender and education level, to be clear, it can be seen in table below. 
Tabel 1.1 Distribution of Frequency Based on Respondents' Age in Environmental Health Department Poltekkes MoH Aceh

\begin{tabular}{|c|c|c|c|}
\hline Variable & Category & $\mathbf{n}$ & $\%$ \\
\hline Age & $\begin{array}{c}\text { 1. }<=30 \text { Years Old } \\
\text { 2. }>30 \text { Years Old }\end{array}$ & $\begin{array}{c}3 \\
20\end{array}$ & $\begin{array}{l}13 \\
87 \\
\end{array}$ \\
\hline Total & & 23 & \\
\hline
\end{tabular}

Source : Data Primer

Table 1.2 Frequency Distribution Based on Length of Work of Respondent in Environmental Health Department of Poltekkes, MoH Aceh

\begin{tabular}{|c|c|c|c|}
\hline Variable & Category & $\mathbf{N}$ & $\%$ \\
\hline Length of & 1. 0 - 5 Years Old & 8 & 34,8 \\
\hline Work & 2. $6-10$ Years Old & 2 & 8,7 \\
\hline & 3. 11 - 15 Years Old & 1 & 4,3 \\
\hline & 4. $>=16$ Years Old & 12 & 52,2 \\
\hline \multicolumn{2}{|l|}{ Total } & 23 & 100 \\
\hline
\end{tabular}

Source: Data primer

Table 1.3: Frequency Distribution Based on Job Satisfaction of Respondent in Environmental Health Department of Poltekkes, MoH Aceh

\begin{tabular}{|c|c|c|c|c|}
\hline Variable & \multicolumn{2}{|c|}{ Category } & n & \% \\
\hline Gender & 1. & Male & 16 & 69,6 \\
& 2. & Female & 7 & 30,4 \\
\hline Jumah & 23 & 100 \\
\hline
\end{tabular}

Source : Data primer

Table 1.4: Frequency Distribution Based on Education of Respondent in Environmental Health Department of Poltekkes, MoH Aceh

\begin{tabular}{|c|c|c|c|}
\hline Variable & Category & $\mathbf{n}$ & $\%$ \\
\hline \multirow[t]{4}{*}{ Education } & $\begin{array}{l}\text { 1. Senior High } \\
\text { School }\end{array}$ & 1 & 4,3 \\
\hline & 2. Diploma-III & 7 & 30,4 \\
\hline & 3. BA degree & 11 & 47,8 \\
\hline & 4. MA degree & 4 & 17,4 \\
\hline \multicolumn{2}{|l|}{ Total } & 23 & 100 \\
\hline
\end{tabular}

Source : Data primer 
Table 1.5 Frequency Distribution Based on Attitude of Respondent in Environmental Health Department of Poltekkes, MoH Aceh

\begin{tabular}{|c|c|c|c|}
\hline Variable & Category & $\mathbf{n}$ & $\%$ \\
\hline \multirow[t]{2}{*}{ Attitude } & 1. Positive & 12 & 52,2 \\
\hline & 2. Negative & 11 & 47,8 \\
\hline \multicolumn{2}{|l|}{ Total } & 23 & 100 \\
\hline
\end{tabular}

Source : Data primer

2) Distribution Description of Characteristic of Workplace Condition

Table 2.1: Frequency Distribution Based on Compensation of Respondents in Environmental Health Department of Poltekkes, MoH Aceh

\begin{tabular}{|c|c|c|c|}
\hline Variable & Category & $\mathbf{n}$ & $\%$ \\
\hline \multirow[t]{2}{*}{ Compensation } & 1. Satisfied & 13 & 56,5 \\
\hline & 2. Unsatisfied & 10 & 43,5 \\
\hline \multicolumn{2}{|l|}{ Total } & 23 & 100 \\
\hline
\end{tabular}

Source : Data primer

Table 2.2: Frequency Distribution Based on Promotion of Respondents in Environmental Health Department of Poltekkes, MoH Aceh

\begin{tabular}{|c|c|c|c|}
\hline Variable & Category & $\mathbf{n}$ & $\%$ \\
\hline Promotion & $\begin{array}{ll}\text { 1. } & \text { Ever } \\
\text { 2. } & \text { Never }\end{array}$ & $\begin{array}{c}9 \\
14\end{array}$ & $\begin{array}{l}39,1 \\
60,9\end{array}$ \\
\hline Total & & 23 & 100 \\
\hline
\end{tabular}

Source : Data primer

Table 2.3: Frequency Distribution According to Colleague of Respondents in Environmental Health Department of Poltekkes, MoH Aceh

\begin{tabular}{|c|l|c|c|}
\hline Variable & Category & n & \% \\
\hline Colleague & 1. Good & 15 & 65,2 \\
& 2. Enough & 8 & 34,8 \\
\hline Total & 23 & 100 \\
\hline
\end{tabular}

Source : Data primer 
Table 2.4: Frequency Distribution According to Supervision of Respondents in Environmental Health Department of Poltekkes, MoH Aceh

\begin{tabular}{|c|l|c|c|}
\hline Variable & \multicolumn{1}{|c|}{ Category } & $\mathbf{n}$ & $\mathbf{\%}$ \\
\hline Supervision Level & 1. Good & 13 & 56,5 \\
& 2. Enough & 10 & 43,5 \\
\hline Total & 23 & 100 \\
\hline
\end{tabular}

Source : Data primer

Table 2.5: Frequency Distribution Based on Level Work of Respondents in Environmental Health Department of Poltekkes, MoH Aceh

\begin{tabular}{|c|c|c|c|}
\hline Variable & \multicolumn{1}{|c|}{ Category } & $\mathbf{n}$ & $\mathbf{~}$ \\
\hline Level Work & 1. Satisfied & 12 & 52,2 \\
& 2. Unsatisfied & 11 & 47,8 \\
\hline Total & 23 & 100 \\
\hline
\end{tabular}

Source: Data primer

3) Result Analysis of Dependent Univarian Variable

Table 3.1: Frequency Distribution Based on Job Saticfaction of Respondents in Environmental Health Department of Poltekkes, MoH Aceh

\begin{tabular}{|c|c|c|c|}
\hline Variable & Category & $\mathrm{n}$ & $\%$ \\
\hline Job Satisfaction & $\begin{array}{l}\text { 1. Satisfied } \\
\text { 2. Unsatisfied }\end{array}$ & $\begin{array}{c}14 \\
9\end{array}$ & $\begin{array}{l}60,9 \\
39,1\end{array}$ \\
\hline Total & & 23 & 100 \\
\hline
\end{tabular}

Source : Data primer

b. Result Analysis of Bivarian

To find out the relationship between individual characteristics and the characteristics of workplace conditions on job satisfaction of Environmental Health Department employee of Poltekkes, Ministry of Health Aceh, bivarian analysis will be done by using a correlation coefficient of contingency.

The relationships individual characteristics and the characteristics of the workplace on job satisfaction Environmental Health Department employee of Poltekkes, Ministry of Health Aceh for more details can be seen as follows: 
1) Bivarian Result for Individual Characteristic and Job Satisfaction

The relationship between individual age characteristics and job satisfaction can be seen in Table 4.1 .

Table 4.1 The Relationship between Age and Job Satisfaction of Environmental Health Department Employee of Poltekkes,MoH Aceh

\begin{tabular}{|c|c|c|c|c|c|}
\hline \multirow[t]{2}{*}{$\begin{array}{l}\text { Individual } \\
\text { Characteristic }\end{array}$} & \multirow[t]{2}{*}{ Category } & \multicolumn{2}{|c|}{$\begin{array}{l}\text { Satisfaction } \\
\text { In Working }\end{array}$} & \multirow[t]{2}{*}{ Total } & \multirow{2}{*}{ P. Value } \\
\hline & & Unsatisfied & Satisfied & & \\
\hline \multirow[t]{2}{*}{ Age } & $\begin{array}{l}1 .<=30 \\
y \\
\text { 2. }>30 y\end{array}$ & 2 & 13 & 20 & 0,295 \\
\hline & Total & 9 & 14 & 23 & \\
\hline
\end{tabular}

Table 4.2: The Relationship between Length of Work and Job Satisfaction of Environmental Health Department Employee of Poltekkes,MoH Aceh

\begin{tabular}{|c|c|c|c|c|c|}
\hline \multirow[t]{2}{*}{$\begin{array}{l}\text { Individual } \\
\text { Characteristic }\end{array}$} & \multirow[t]{2}{*}{ Category } & \multicolumn{2}{|c|}{$\begin{array}{l}\text { Satisfaction } \\
\text { In Working }\end{array}$} & \multirow[t]{2}{*}{ Total } & \multirow[t]{2}{*}{ P.value } \\
\hline & & Unsatisfied & Satisfied & & \\
\hline \multirow{7}{*}{$\begin{array}{l}\text { Length of } \\
\text { Work }\end{array}$} & 1. $0-5$ & 4 & 4 & 8 & \multirow{7}{*}{0,727} \\
\hline & 2. $6-10$ & 1 & 1 & 2 & \\
\hline & Year & & & & \\
\hline & 3. $11-15$ & 0 & 1 & 1 & \\
\hline & $\begin{array}{l}\text { Year } \\
4 .>15\end{array}$ & & & & \\
\hline & Tahun & 4 & 8 & 12 & \\
\hline & Total & 9 & 14 & 23 & \\
\hline
\end{tabular}

Source: Data Primer

Next, the relationship between education level of individual characteristic and job satisfaction can be seen on table 4.3 
Teuku Salfiyadi

Table 4.3 The Relationship Between Education and Job Satisfaction of Environmental Health Department Employee of Poltekkes, MoH Aceh

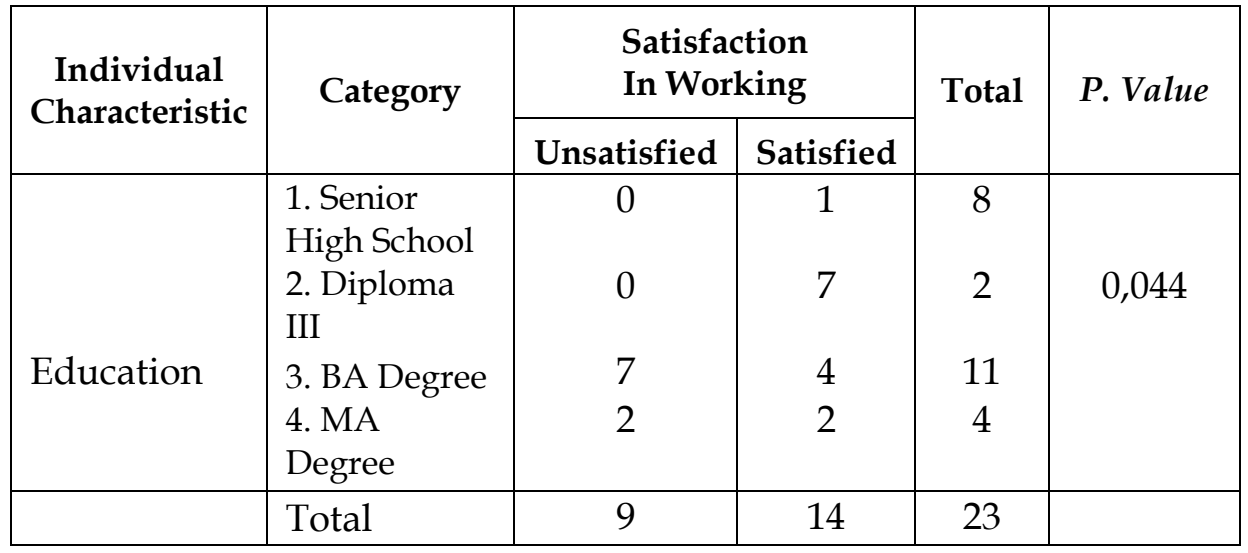

Table 4.4 The Relationship Between Attitude and Job Satisfaction of Environmental Health Department Employee of Poltekkes, MoH Aceh

\begin{tabular}{|l|l|c|c|c|l|}
\hline \multirow{2}{*}{$\begin{array}{c}\text { Individual } \\
\text { Characteristic }\end{array}$} & \multirow{2}{*}{ Category } & \multicolumn{2}{|c|}{$\begin{array}{c}\text { Satisfaction } \\
\text { In Working }\end{array}$} & \multirow{2}{*}{ Total } & \multirow{2}{*}{ P.value } \\
\cline { 3 - 5 } & & Unsatisfied & Satisfied & & \\
\hline Attitude & 1. Positive & 2 & 10 & 12 & \multirow{2}{*}{0,021} \\
& 2. Negative & 7 & 4 & 11 & \\
\hline & Total & 9 & 14 & 23 & \\
\hline
\end{tabular}

2) Bivarian Result for Workplace Characteristic and Job Satisfaction

Relationship between compensation of workplace characteristic and job satisfaction can be seen on Table 4.5.

Based on Table 4.5, it was obtained by $\mathrm{p}$ value of 0.000 which value is less than 0.05. Thus we must reject the null hypothesis, which means, there is a real relationship between compensation and job satisfaction in Health Polytechnic, MoH Aceh. 
Table 4.5: The Relationship Between Compensation and Job Satisfaction of Environmental Health Department Employee of Poltekkes, MoH Aceh

\begin{tabular}{|l|l|c|c|c|l|}
\hline \multirow{2}{*}{$\begin{array}{c}\text { Workplace } \\
\text { Characteristic }\end{array}$} & Category & \multicolumn{2}{|c|}{$\begin{array}{c}\text { Satisfaction } \\
\text { In Working }\end{array}$} & \multirow{2}{*}{ Total } & \multirow{2}{*}{ P.value } \\
\cline { 3 - 5 } & & Unsatisfied & Satisfied & & \\
\hline Compensation & 1 & 12 & 13 & \multirow{2}{*}{0,000} \\
& 1. Satisfied & 1 & 2 & 10 & \\
\hline & 2. Unsatisfied & 8 & 14 & 23 & \\
\hline & Total & 9 & & & \\
\hline
\end{tabular}

Next, the relationship between promotion of workplace characteristic and job satisfaction can be seen on Table 4.6

Tabel 4.6 The Relationship Between Promotion and Job Satisfaction of Environmental Health Department Employee of Poltekkes, MoH Aceh

\begin{tabular}{|l|l|c|c|c|l|}
\hline \multirow{2}{*}{$\begin{array}{c}\text { Workplace } \\
\text { Characteristic }\end{array}$} & Category & \multicolumn{2}{|c|}{$\begin{array}{c}\text { Satisfaction } \\
\text { In Working }\end{array}$} & \multirow{2}{*}{ Total } & \multirow{2}{*}{ P.value } \\
\cline { 3 - 5 } & & Unsatisfied & Satisfied & & \\
\hline Promotion & 1. Ever & 0 & 9 & 9 & \multirow{2}{*}{0,002} \\
& 2. Never & 9 & 5 & 14 & \\
\hline & Total & 9 & 14 & 23 & \\
\hline
\end{tabular}

Table 4.7: The Relationship Between Colleague and Job Satisfaction of Environmental Health Department Employee of Poltekkes, MoH Aceh

\begin{tabular}{|l|l|c|c|c|l|}
\hline \multirow{2}{*}{$\begin{array}{c}\text { Workplace } \\
\text { Characteristic }\end{array}$} & Category & \multicolumn{2}{|c|}{$\begin{array}{c}\text { Satisfaction } \\
\text { In Working }\end{array}$} & \multirow{2}{*}{ Total } & \multirow{2}{*}{ P.value } \\
\cline { 3 - 5 } & & Unsatisfied & Satisfied & & \\
\hline Colleague & 1. Good & 3 & 12 & 15 & \multirow{2}{*}{0,010} \\
& 2. Enough & 6 & 2 & 8 & \\
\hline & Total & 9 & 14 & 23 & \\
\hline
\end{tabular}


Teuku Salfiyadi

Table 4.8: The Relationship Between Supervision and Job Satisfaction of Environmental Health Department Employee of Poltekkes, MoH Aceh

\begin{tabular}{|l|c|c|c|c|l|}
\hline \multirow{2}{*}{$\begin{array}{c}\text { Workplace } \\
\text { Characteristic }\end{array}$} & \multirow{2}{*}{ Category } & \multicolumn{2}{|c|}{$\begin{array}{c}\text { Satisfaction } \\
\text { In Working }\end{array}$} & \multirow{2}{*}{ Total } & \multirow{2}{*}{ P.value } \\
\cline { 3 - 5 } & & Unsatisfied & Satisfied & & \\
\hline \multirow{3}{*}{ Supervision } & 1. Good & 2 & 11 & 13 & \multirow{2}{*}{0,008} \\
& 2. Enough & 7 & 3 & 10 & \\
\hline & Total & 9 & 14 & 23 & \\
\hline
\end{tabular}

Then, relationship between level work characteristic and job satisfaction can be seen on Table 4.9

Table 4.9: The Relationship Between Level Work Characteristic and Job Satisfaction of Environmental Health Department Employee of Poltekkes, MoH Aceh

\begin{tabular}{|c|c|c|c|c|c|}
\hline \multirow{2}{*}{$\begin{array}{c}\text { Workplace } \\
\text { Characteristic }\end{array}$} & \multirow{2}{*}{ Category } & \multicolumn{2}{|c|}{$\begin{array}{c}\text { Satisfaction } \\
\text { In Working }\end{array}$} & \multirow{2}{*}{ Total } & \multirow{2}{*}{ P.value } \\
\cline { 3 - 5 } & & Unsatisfied & Satisfied & & \\
\hline \multirow{2}{*}{ Job } & 1. Satisfied & 2 & 10 & 12 & \multirow{2}{*}{0,021} \\
& 2. Unsatisfied & 7 & 4 & 11 & \\
\hline & Total & 9 & 14 & 23 & \\
\hline
\end{tabular}

\section{E. Conclusion}

Individual characteristics and the characteristics of the Workplace

a) From these results, indicating no significant relationship between attitude, discipline and patience of the level on job satisfaction.

b) While the views of workplace conditions also had a significant relationship between compensation, promotion, supervision and job satisfaction levels of employees. 


\section{Bibliography}

Hughes, K. J., \& Batten, L. (2016). The Development of Social and Moral Responsibility in Terms of Respect for the Rights of Others. Jurnal Ilmiah Peuradeun, 4(2), 147-160.

Kusman, Ariyanto, (2008), Characteristics Influence of Organizational Commitment Against.

Malthis, Robert L, (1996), Human Resource Management, Jakarta, PT Salemba Emban Patria.

Miftha, Thoha (2007). Manajemen Kepegawaian Sipil di Indonesia, Jakarta: Kencana.

Muljani, N. (2002). Kompensasi Sebagai Motivator Untuk Meningkatkan Kinerja Karyawan. Jurnal Manajemen dan Kewirausahaan. 4(2), 108-122.

Muttaqin, F. (2015). Early Feminist Consciousness and Idea Among Muslim Women in 1920s Indonesia. Jurnal Ilmiah Peuradeun, 3(1), 19-38.

Nurhasanah, N., \& Nida, Q. (2016). Character Building of Students by Guidance and Counseling Teachers Through Guidance and Counseling Services. Jurnal Ilmiah Peuradeun, 4(1), 65-76.

Patimah, S. (2015). Pengaruh Rekrutmen dan Seleksi Terhadap Kinerja Kepala Madrasah Ibtidaiyah Negeri (MIN) Sekota Bandar Lampung. Jurnal Ilmiah Peuradeun, 3(1), 165-190.

Poltekkes Kemenkes Aceh, (2005). Renstra Poltekkes Kemenkes Aceh.

Rivai Veithzal (2009). Manajemen Sumber Daya Manusia Untuk Perusahaan Dari Teori ke Praktek, Jakarta: Rajawali Pers.

Robbins, S.P.(1996), Organizational behavior (Vol. I), Translation by Pujaatmaka, H. Jakarta, PT.Prenhallindo.

Sarboini, S. (2016). Performance of Employees and Impact on Promotion of Position. Jurnal Ilmiah Peuradeun, 4(1), 103-114.

Sastrohadiwiryo, Siswanto (2010). Pengantar Manajemen, Jakarta: Bumi Aksara.

Sedarmayanti (2001). SDM dan Produktivitas Kerja. Bandung: Mandar Maju.

Sopiah (2008). Perilaku Organisasi, Yogyakarta: Andi.

Tjahjono, H.K. (2007). Validasi Item-Item Keadilan Distributif dan Keadilan Prosedural: Aplikasi Structural Equation Modeling (SEM) dengan Confirmatory Factor Analysis (CFA). JMA, 18(2), 115-125. 